\title{
The Effect of Economic Growth and Poverty on Development Disparities in West Java Province
}

\author{
Dyah Poespita Ernawati \\ Institut Pemerintahan Dalam Negeri, Sumedang, Indonesia \\ dyah.poespita1968@gmail.com
}

\begin{abstract}
The purpose of this study is to ascertain the influence of economic growth on development inequalities in West Java Province and on employment in the province. The data utilized in this study are secondary data from the Central Statistics Agency (BPS) from 2010 to 2019. The descriptive and multiple linear regression analyses were employed in this study. $\backslash$. The results showed that the development disparity in West Java was high, as indicated by the Williamson index between 0.61 and 0.70. This study also found that economic growth partially and simultaneously had no significant effect on development disparities in West Java, and poverty also partly and simultaneously did not significantly affect development disparities in West Java.
\end{abstract}

\section{Keywords}

economic growth; development disparities; poverty

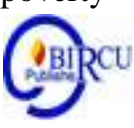

\section{Introduction}

The economic development of a country has the ultimate goal of improving people's welfare. To achieve this goal, high economic growth and an even distribution of income are required (Sulistiawati, 2012). However, the geographical condition of Indonesia in the form of an archipelago is one of the obstacles to implementing equitable development in each region. Therefore, regional autonomy policy can create better development because this policy will increase economic growth and community welfare. In addition, local governments will be more efficient in managing the resources available in each region and providing public goods to facilitate activities economy (Nurzen \& Riharjo, 2016).

Kuncoro (2004) states that development within the scope of the country is spatially not always evenly distributed. There are regions with fast growth and areas with slow growth. The equitable distribution of income needs to be considered in regional development because according to Senik (2005), income inequality will have a detrimental effect on economic growth. Then the region's people's welfare will deteriorate. Unbalanced economic growth might result in development inequalities. The disparity in economic development between areas is a universal phenomenon; disparity in development is a severe gap problem in both the market economy and planned economies (Nurhuda, 2013).

According to Santosa (2015), in Indonesia, inequality between regions is not only historical heritage, but also because development policies have emphasized more on economic growth and equitable development among community groups and have not been significant in focusing on equitable distribution of equitable distribution development between regions. Furthermore, this inequality is also reinforced by differences in regional characteristics, quantity, quality of human resources, and the completeness of the infrastructure.

Economic growth that is both rapid and sustainable is a precondition or a requirement for the continuation of economic development and welfare improvement; because the population grows each year, it is required to raise income each year. Economic 
development that is not accompanied by more job possibilities will result in increased disparity in the allocation of more money, therefore creating a condition of economic growth that produces reality, namely an increase in poverty (Dama, 2016).

Economic growth is also closely related to poverty and equitable development (income distribution). The poverty-economic growth-inequality triangle shows a continuous interaction between these three factors. Economic growth and income distribution will help accelerate poverty alleviation in a country. On the other hand, widening economic inequality hurts economic growth (Yuliani, 2015). Poverty can be said to be the situation of a society with a weak economy. Coupled with government policies that are usually aimed at solving short-term problems, these policies have failed to address the lower class of the economy. In addition, the influence of foreign conditions, especially in terms of development funds. Poverty is a significant problem for the poor in every region; several factors affect poverty, including economic growth, Human Development Index (HDI) and population (Zuhdiyaty \& Kaluge, 2017).

\section{Review of Literature}

\subsection{Economic Growth}

Economic growth is a phrase that refers to a rise in a country's long-term capability to offer a variety of economic benefits to its citizens. The growth in accommodation is determined or enabled by technical, institutional, and ideological advancements or adaptations to present needs (Todaro \& Smith, 2000). Economic growth that is both rapid and sustainable is a fundamental prerequisite, if not a must, for the continuation of economic progress and greater wellbeing. Economic growth is the year-over-year increase in the level of economic activity (Anggoro, 2015).

To find out the rate of economic growth, it is necessary to compare national income, which is calculated based on fundamental values. So changes in national income are only caused by changes in the level of economic activity. In other words, new growth is achieved if the number of goods and services produced increases in the following year (Lamere \& Tatuh, 2016). Therefore, to find out whether the economy is experiencing growth, it is necessary to distinguish the real GRDP of one year from the real GRDP of the previous year.

\subsection{Poverty}

The concept of poverty is quite broad; this diversity is due to the fact that the problem has proliferated on a multidimensional level, which means that poverty is connected to many dimensions of human needs. Inability to maintain a minimal level of living in accordance with one's life narrative is termed poverty (Todaro, 1977). Poverty is a state or condition in which a person or community lacks the financial resources and essentials for a minimum standard of living (Ismail, 2020).

Poverty is defined as a low standard of living, i.e., a state of material deprivation in comparison to the commonly accepted standard of living in society. Economically, poverty can also be defined as a scarcity of resources capable of enhancing a group's wellbeing (Suliswanto, 2010). As a result, poverty may also be described as "the inability to maintain a subsistence level of life." Food, clothes, shelter, education, and health are all fundamental requirements that must be addressed (Sidiq \& Jalil, 2021; Jacobus et al., 2021). Thus, poverty, as defined by the Central Statistics Agency, is the inability to fulfill the bare essentials, including food and non-food necessities. 
Poverty may be quantified by comparing an individual's consumption level to the poverty line or by calculating the monthly rupiahs spent on consumption. While the poor are defined as individuals with an average monthly per capita expenditure that is less than the poverty level (Amaliah, 2016). The poverty line in the neighborhood is calculated for those earning less than IDR 7,057 per day. The value of IDR 7,057 per person per day is derived from the poverty line calculation, which takes into account both food and non-food needs. The minimal daily calorie requirement for food is 2,100 kilocalories per capita. The non-food poverty line represents the bare minimal requirement for housing (land area, access to clean water, and large-scale sewage infrastructure); education (literacy rate, 9year obligatory schooling, and dropout rate); and health (low consumption of nutritious food, lack of health facilities and inadequate sanitation and environmental conditions).

Giovanni (2018) believes that poverty is not just a question of income but also of the qualities that a person must possess, one of which is access to education, health, and employment possibilities. Thus, poverty will be addressed more comprehensively. Wijayanto and Arianti (2010) see poverty from two perspectives, namely: 1. Absolute Poverty Absolute poverty is defined as poverty linked with an estimated level of income and requirements that are confined to the most basic or bare necessities for survival. Thus, poverty is defined as the difference between an individual's income and the money required to satisfy their fundamental requirements, namely food, clothes, and housing, in order to survive. 2. Relative Poverty is poverty that is viewed through the lens of social inequality, since there are persons who have met their bare essential requirements yet remain significantly poorer than the surrounding population. The bigger the economic disparity between the high and lower classes, the higher the number of people who may be classified as inferior, and so poverty is pretty strongly connected to the income distribution problem.

\subsection{Development Disparity}

The development process in an area will bring up a general phenomenon, namely the inequality of development between regions, which will have implications for the regional development process and the area's welfare level. In general, the substances that arise are social jealousy and public dissatisfaction with the results of development. According to Imelia (2006), the indicators used to analyze inequality between regions are GRDP, household consumption per capita, sectoral contribution to GRDP, poverty level and fiscal structure.

In the interregional perspective, inequality occurs both in terms of the income level of people from one region to another, as well as in terms of income distribution among residents of each area. Regional inequalities in development can be identified, among others, by examining striking differences in aspects such as employment, allocation of banking funds, investment and growth (Santosa, 2015).

The Williamson Index, developed by Jeffrey G. Williamson in 1966, is used to determine regional development disparity. This index is a coefficient of variance that is frequently used in statistical research to quantify a difference. Thus, the title Williamson Index is a nod to early index users who quantified regional differences in development. Although this index has numerous flaws, it is very dependent on the area definition employed in the calculation. However, this indicator is frequently employed to quantify regional disparities in development. 


\subsection{Relationship between Economic Growth and Development Disparities}

Kuznets stated that the relationship between growth and inequality is like an inverted U-shaped, i.e. in the short term, there is a positive correlation. Still, in a long time, the relationship becomes negative. This means that in the early stages of development, the level of inequality will get more significant to a certain level and then the level of inequality will decrease (Nurhuda, 2013). According to Sasana (2009), in his research, government spending used to increase economic growth can reduce the development gap between regions; in other words, equity will be achieved if the economic growth of each area rises gradually (Sidiq \& Achmad, 2020).

The classical economists Roberti (1974), Hayani and Rufffan (1985) suggest that economic growth will always reduce poverty and income inequality even though it is still in the early stages of development. Empirical evidence from the content view is based on observations in several countries such as Taiwan, Hong Kong, Singapore, China. The Neoclassical group is very optimistic that economic growth in practice tends to reduce income inequality and poverty. Rich and poor. This happens because of the accumulation of capital and technological advances typical to increase the concentration of resource and capital control by the capitalist rulers of the "elite" group of society. On the other hand, nonowners of capital will remain in a state of poverty.

\subsection{The Relationship of Poverty to Development Disparities}

Even if income has increased to meet bare basic necessities, it is still much less than that of the surrounding population, indicating that the individual is still inferior. This is because poverty is defined more by the conditions around an individual than by the individual's surroundings. Relative poverty is a state of deprivation caused by the absence of development strategies at all levels of society, resulting in economic disparity (Suryawati, 2005; Poluakan, et.all, 2019).

Poverty and inequality in development are inseparable elements. Poverty exists due to social inequality in a country. Most of a nation's income can only be enjoyed by a handful of people, and others only get a small portion or even do not get it. The influence of the poverty level on inequality has a negative effect, namely where when the poverty level increases, it will also increase the economic disparity that will occur. Social inequality is a severe problem, especially in developing areas, because development inequality is the forerunner to the formation of poverty and various kinds of social issues, which takes a long time. Therefore, equitable development should be realized immediately so as not to cause disparities between regions.

\section{Research Methods}

The type of research used is quantitative research. The data used in this study is secondary data obtained from official sources of the relevant agencies (namely the Central Statistics Agency) in the form of data on GRDP, poverty, and development inequality in West Java Province in 2010-2019. The measure of development inequality analyses how big the gap is between regions/regions by using the Williamson Index calculation method. The analytical method used is multiple linear regression modal. According to Sugiyono (2013), multiple linear regression analysis is used to forecast how the dependent variable's condition (up and down) would change when two or more independent variables are modified as predictor factors. The purpose of regression analysis is to estimate and forecast the value of $\mathrm{X}$ given its value. The link between economic growth factors and poverty levels on development inequality was changed for this study to reflect the research findings. 


\section{Results and Discussion}

\subsection{Economic Growth in West Java Province}

To see how much economic growth occurred in West Java Province, this was measured based on the Gross Regional Domestic Product (GRDP) at constant prices that were successfully created in a given year compared to the previous year's value. This continuous price basis is intended to avoid the effect of price changes so that the changes measured are real economic growth and the basis for calculating the added value arising from economic activities in one area. The growth and development of GRDP of West Java Province can be viewed from several macro indicators, namely the added value generated by the regional economic structure and Gross Regional Domestic Product (GRDP). The Gross Regional Domestic Product of West Java Province in 2010-2019 at constant prices in 2010 fluctuated; this can be seen in Table 1 .

Table 1. Development of Economic Growth in 2010-2019

\begin{tabular}{|c|c|r|}
\hline Year & $\begin{array}{c}\text { GRDP at constant } \\
\text { prices (Billions) }\end{array}$ & $\begin{array}{c}\text { Growth rate } \\
(\mathbf{\%})\end{array}$ \\
\hline 2010 & $906,685.76$ & 6.50 \\
\hline 2011 & $965,622.06$ & 6.50 \\
\hline 2012 & $1,028,409.74$ & 6.33 \\
\hline 2013 & $1,093,543.55$ & 5.85 \\
\hline 2014 & $1,157,567.23$ & 4.26 \\
\hline 2015 & $1,206,891.27$ & 5.83 \\
\hline 2016 & $1,277,312.17$ & 5.76 \\
\hline 2017 & $1,350,879.84$ & 5.91 \\
\hline 2018 & $1,430,710.19$ & 5.18 \\
\hline 2019 & $1,504,776.35$ & \\
\hline
\end{tabular}

Source: Processed by researcher

Table 1 shows the economic growth conditions of West Java Province in 2011 and 2012. Economic growth was stagnant at 6.50 per cent. In some sectors of the economy, there has been a decline while other sectors such as agriculture and manufacturing have increased. In 2014-2015 economic growth in West Java Province decreased by 5.85 per cent and 4.26 per cent, respectively. However, in 2016-2018 economic growth increased again by 5.83 per cent, 5.76 per cent and 5.91 per cent; this was due to the increase in agriculture and manufacturing and several other economic sectors. But in 2019, there was a decrease of 5.18 per cent.

\subsection{Poverty Level}

The number and development of poverty in the province of West Java can be seen in Table 2 below:

Table 2. Poverty Development of West Java Province

\begin{tabular}{|c|c|c|c|}
\hline Year & $\begin{array}{c}\text { Poverty } \\
\text { (Thousand) }\end{array}$ & $\begin{array}{c}\text { Percentage of Poor } \\
\text { Population }(\boldsymbol{\%})\end{array}$ & $\begin{array}{c}\text { Growth } \\
\mathbf{( \% )}\end{array}$ \\
\hline 2010 & $4,716.8$ & 11.27 & -0.7 \\
\hline 2011 & $4,650.9$ & 10.57 & -0.69 \\
\hline 2012 & $4,430.2$ & 9.88 & \\
\hline
\end{tabular}




\begin{tabular}{|l|c|c|c|}
\hline 2013 & $4,375.2$ & 9.61 & -0.27 \\
\hline 2014 & $4,239.0$ & 9.18 & -0.43 \\
\hline 2015 & $4,435.70$ & 9.53 & 0.35 \\
\hline 2016 & $4,224.32$ & 8.95 & -0.58 \\
\hline 2017 & $4,168.4$ & 8.71 & -0.24 \\
\hline 2018 & $3,615.8$ & 7.45 & -1.26 \\
\hline 2019 & $3,399.2$ & 6.91 & -0.54 \\
\hline
\end{tabular}

Source: Processed by researcher

In Table 2 above, it can be seen that during 2010-2014 there was a decrease in the percentage of poverty, from 11.27 per cent to 9.18 per cent. . However, the percentage of poverty increased in 2015 in the range of 9.53 per cent. In 2016-2019 the poverty rate decreased by 8.95 per cent, 8.71 percent, 7.45 per cent, and 6.91 percent, respectively. It can be seen that the percentage of poor people is still relatively high even though the poverty rate has decreased. The condition of this high poverty rate is one indicator of the welfare level of the people of West Java who are still entangled with the problem of poverty. Compared with the trillions of APBD funds that flow to West Java Province every year, the abundance of the budget still has not positively impacted reducing poverty. Including the problem of unemployment which is one of the causes of poverty.

\subsection{Development Disparity}

To determine the level of success of economic development inequity between regions, the indicator of equity can be used, namely the Williamson Index. Comparison of this index from year to year will show whether there is a change or not. For example, where the coefficient value of the Williamson Index is from 0 to 1 , if the coefficient value is close to 0 , then the level of inequality that occurs is getting smaller. On the other hand, if the coefficient value is close to 1 , it means the level of inequality is getting higher.

Table 3. Development of the Williamson Index of West Java Province in 2010-2019

\begin{tabular}{|c|c|l|}
\hline Year & $\begin{array}{c}\text { Williamson Index } \\
\text { Value (W) }\end{array}$ & \multicolumn{1}{|c|}{ Information } \\
\hline 2010 & 0.68 & High level of inequality \\
\hline 2011 & 0.68 & High level of inequality \\
\hline 2012 & 0.69 & High level of inequality \\
\hline 2013 & 0.62 & High level of inequality \\
\hline 2014 & 0.61 & High level of inequality \\
\hline 2015 & 0.61 & High level of inequality \\
\hline 2016 & 0.70 & High level of inequality \\
\hline 2017 & 0.70 & High level of inequality \\
\hline 2018 & 0.69 & High level of inequality \\
\hline 2019 & 0.68 & High level of inequality \\
\hline
\end{tabular}

Source: Processed by researcher

It can be seen in Table 3 above that the development of disparity in West Java Province during 2010-2019 from the results of the Williamson index fluctuated. According to the Central Bureau of Statistics of West Java Province, this is due to the uneven distribution of economic growth in several districts of West Java Province. The lowest level of inequality occurred in 2014 and 2015 where the Williamson Index value was 0.61. 
Meanwhile, the highest level of inequality occurred in 2016 and 2017, with a Williamson index value of 0.70 . The higher the level of inequality that happens, will worsen the economic condition of a region.

The high level of inequality occurs because economic and development activities are only centred in a few areas, such as the city of Bandung as the capital and several other sites that are used as industrial centres such as Bekasi City, Bekasi Regency, and Karawang, which are in the northern region of West Java, with an area of large enough, developments in one of these areas may not affect all sizes. As a result, some areas are progressing rapidly while others are not. Since 2015, the West Java provincial government has begun to carry out other developments, such as revitalizing and developing industrial estates in Bekasi, Karawang, Purwakarta, Majalengka, Subang, Sukabumi to the southern part of West Java. In addition, the development of an Effective and Efficient logistics system, by building infrastructure including the construction of the Cilamaya port, Kertajati Airport and various toll roads that connect economic centres. This seems to be starting to reduce inequality in West Java, although it is not too significant.

\subsection{Hypothesis Testing Results}

To find out how much influence economic growth and poverty partially have on inequality in West Java Province, this study uses a statistical t-test to test these variables. This test was conducted to test whether the independent variables (Economic Growth and Poverty) partially affected the dependent variable (Disparity). This test is seen from each statistic from the regression with $t$ table in rejecting and accepting the hypothesis. Multiple linear regression testing was carried out using SPSS version 22 (Ghozali, 2011).

Table 4. Hypothesis Testing Results

\begin{tabular}{|c|c|c|c|c|c|}
\hline \multirow{2}{*}{ Model } & $\begin{array}{c}\text { Unstandardized } \\
\text { Coefficients }\end{array}$ & $\begin{array}{c}\text { Standardized } \\
\text { Coefficients }\end{array}$ & $\begin{array}{c}\text { Standardized } \\
\text { Coefficients }\end{array}$ & $\mathbf{t}$ & Sig. \\
\cline { 2 - 6 } & $\mathbf{B}$ & Std Error & Beta & & \\
\hline (Constant) & .350 & .595 & & .587 & .574 \\
\hline Economic Growth & .076 & .208 & .147 & .368 & .723 \\
\hline Poverty & -.106 & .475 & -.089 & -.223 & .828 \\
\hline $\mathrm{R}=0.142$ & $\mathrm{~F}_{\text {count }}=0.072 \quad$ Sig $=0.929$ \\
$\mathrm{R}^{2}=0.020$
\end{tabular}

Based on Table 4, the equation can be obtained where: $\mathrm{Y}=0.350+0.076 \mathrm{X} 1-0.106$ $\mathrm{X} 2$. The regression equation describes a constant with a value of 0.350 ; this shows that if the variables of economic growth and poverty are fixed (constant), then the value of inequality is 0.350 . The regression coefficient of the economic growth variable $(\mathrm{X} 1)$ value is 0.076 ; this shows that if the economic growth variable has increased by 1 per cent, then the inequality value has increased by 0.076 . The regression coefficient for the poverty variable $(\mathrm{X} 2)$ is -0.106 , and this indicates that if the poverty variable has risen by 1 per cent, the inequality value has increased by -0.106 .

\subsection{T-test (Individual Parameter Significance Test)}

From the results of hypothesis testing using SPSS Statistics 22, the value of $t_{\text {count }}<$ $\mathrm{t}_{\text {table }}(0.076<0.723)$ is based on the results of testing the hypothesis, then Ho is accepted, which means that part there is no significant effect between the X1 variable (economic growth) on the dependent variable (Disparity). So from the results of testing the hypothesis, it can be concluded that partially the X1 variable (economic growth) does not affect the dependent variable (disparity) in West Java Province. 
Then the results of hypothesis testing for the variable X2 (poverty) are obtained $t_{\text {count }}>-t_{\text {table }}(-0.106>-0.828)$ based on these results, then Ho is accepted, which means that part there is no significant effect between the X2 variable (poverty) on the dependent variable (inequality). Thus, from testing the hypothesis, it can be concluded that partially the X2 variable (poverty) does not affect the dependent variable (disparity) in West Java Province.

\subsection{F Test (Simultaneous Significance)}

Based on the results of hypothesis testing, the value of $F_{\text {count }}<F_{\text {table }}(0.072<0.929)$. Following these results, Ho is accepted, which means that the variable X1 (economic growth) and variable X2 (poverty) simultaneously does not affect the dependent variable (inequality) in West Java Province.

\subsection{Coefficient of Determination ( $\mathrm{R} 2)$}

The R2 ( $\mathrm{R}$ square) score is 0.020 or 2.0 percent based on findings of hypothesis testing. This demonstrates that the percentage contribution to the dependent variable (inequality) from the effect of the independent variable (economic growth and poverty) is just $2.0 \%$. At the same time, other variables not included in this study model impact the remaining 98 percent.

\subsection{The Effect of Economic Growth on Development Disparities}

Based on the findings of hypothesis testing, the value of count ttable $(0.076<0.723)$ is rejected, indicating that the economic growth variable has a limited effect on the disparity variable in West Java Province. West Java Province's development disparity is classified as significant inequality. Among the factors contributing to economic and social disparity in West Java Province are the province's continued unequal growth between the northern and southern parts. This situation creates difficulties for West Java Province in terms of enhancing, equalizing, and expanding the reach and quality of health, education, and health services. And other social services, as well as the distance between information sources in the region's various corners. The findings of this study are consistent with those of Pangkiro's (2016) research, indicating that economic expansion has little effect on Development Disparities.

This demonstrates that the economic development that has happened has not addressed inequality. Economic growth happens as a result of contributions to low-laborintensity industries. Meanwhile, the industry with the largest employment continues to be a drag on economic development. This is in contrast to Soleh's (2014) research, which demonstrates that economic growth has a positive and substantial effect on development inequalities. This implies that a tiny number of people, or around $20 \%$ of the high-income group, controls nearly $50 \%$ of growth. This group comprises critical production elements such as capital and human resources with a high rate of productivity. Thus, they are a tiny number of people who benefit from economic development and contribute to increased inequality.

\subsection{The Effect of Poverty on Development Disparities}

The results of hypothesis testing in this study explain that the poverty variable does not affect the inequality that occurs in West Java Province. The results showed the value of -count $<$ - ttable $(-0.106>-0.828)$. Based on these results, Ho was rejected, which means that partially the poverty variable does not affect the development inequality variable in West Java Province. When poverty increases by -0.106 , inequality decreased by -0.828 ; 
this clearly shows that increasing poverty does not increase the development inequality in West Java Province. This study explains that the poverty variable does not affect the inequality variable in West Java Province. This is the same as Sudarlan's (2015) research entitled explaining that poverty does not affect inequality; this means that increasing or decreasing the number of poor people will not affect inequality. However, this is not following the results of Soleh's research (2014), with the conclusion that pressure on poverty will hurt development disparities.

From the two research results, it can be seen that there are differences of opinion about the effect of the poverty variable on the inequality variable. For example, in Sudarlan's research (2015), the poverty variable does not affect the disparity variable, but the analysis of Soleh (2014) explains that the poverty variable affects the disparity variable. Therefore, the results of this study can be concluded that the poverty variable does not affect the Inequality variable in West Java Province; inequality in West Java Province is more influenced by other factors not included in this study.

\section{Conclusion}

Based on the development of the disparity of West Java Province during 2010-2019 shown by the Williamson index, it is included in high inequality with a $\mathrm{W}$ value ranging from 0.61 to 0.70 ; the higher the Williamson index value, the worse the economic level of the area. This disparity occurs because development is only centred on a few areas, especially in the northern part of West Java while the southern part of West Java. The Hypothesis Test results showed that economic growth did not affect development disparities where tcount $<$ ttable $(0.076<0.723)$. Meanwhile, the poverty variable also has no effect on development disparities where - value -count $<-$ ttable $(-0.106>-0.828)$. The simultaneous test also obtained the value of Fcount $<$ Ftable $(0.072<0.929)$, which means that economic growth and poverty simultaneously do not affect development disparities.

\section{References}

Amaliah, D. (2016). Pengaruh Partisipasi Pendidikan Terhadap Persentase Penduduk Miskin. Jurnal Faktor UNINDRA, 2(3).

Anggoro, M. H. (2015). Pengaruh Pertumbuhan Ekonomi Dan Pertumbuhan Angkatan Kerja Terhadap Tingkat Pengangguran Di Kota Surabaya. Jurnal Pendidikan Ekonomi (JUPE), 3(3).

Dama, H. Y. (2016). Pengaruh Produk Domestik Regional Bruto (PDRB) Terhadap Tingkat Kemiskinan di Kota Manado (Tahun 2005-2014). Jurnal Berkala Ilmiah Efisiensi, 16(3).

Ghozali, I. (2011). Aplikasi analisis multivariate dengan program IBM. Semarang: Undip.

Giovanni, R. (2018). Analisis Pengaruh PDRB, Pengangguran dan Pendidikan Terhadap Tingkat Kemiskinan di Pulau Jawa Tahun 2009-2016. Economics Development analysis journal, 7(1), 23-31.

Imelia, E. (2006). Modul Ekonomi Regional. Jambi: Unja Press.

Ismail, et al. (2020). The Community Perceptions of Poverty in Gampong Ayon, Seulimeum Sub-district, Aceh Besar Regency (Research Results on March 2017). Budapest International Research and Critics Institute-Journal (BIRCI-Journal). P. 270-275 
Jacobus, E. H., Kindangen, P., \& Walewangko, E. N. (2021). Analisis Faktor-Faktor Yang Mempengaruhi Kemiskinan Rumah Tangga Di Sulawesi Utara. Jurnal Pembangunan Ekonomi Dan Keuangan Daerah, 19(3), 86-103.

Kuncoro, M. (2004). Otonomi dan Pembangunan Daerah: Reformasi, Perencanaan, Strategi, dan Peluang. Jakarta: Erlangga.

Lamere, Z., \& Tatuh, J. (2016). Kesenjangan Pertumbuhan Ekonomi di Provinsi Maluku. AGRI-SOSIOEKONOMI, 12(1A), 121-132.

Nurhuda, R. (2013). Analisis Ketimpangan Pembangunan (Studi di Provinsi Jawa Timur Tahun 2005-2011). Jurnal Administrasi Publik, 1(4), 110-119.

Nurhuda, R. (2013). Analisis Ketimpangan Pembangunan (Studi Di Provinsi Jawa Timur Tahun 2005-2011). Jurnal Administrasi Publik, 1(4), 110-119.

Nurzen, M., \& Riharjo, I. B. (2016). Pengaruh Pertumbuhan Ekonomi, Pendapatan Asli Daerah Dan Dana Alokasi Umum Terhadap Belanja Modal. Jurnal Ilmu Dan Riset Akuntansi (JIRA), 5(4).

Pangkiro, H. A. (2016). Analisis Pertumbuhan Ekonomi Dan Kemiskinan Terhadap Tingkat Ketimpangan Di Provinsi Sulawesi Utara. Jurnal Berkala Ilmiah Efisiensi, $16(1)$.

Poluakan, M. V., Dikayuana, D., Wibowo, H., \& Raharjo, S. T. (2019). Potret Generasi Milenial pada Era Revolusi Industri 4.0. Focus: Jurnal Pekerjaan Sosial, 2(2), 187197.

Santosa, S. H. (2015). Disparitas Pertumbuhan Ekonomi dan Pembangunan Ekonomi Wilayah Di Satuan Wilayah Pembangunan IV Propinsi Jawa Timur. Media Trend, $10(2), 138-155$.

Sasana, H. (2009). Analisis Dampak Pertumbuhan Ekonomi, Kesenjangan Antar Daerah Dan Tenaga Kerja Terserap Terhadap Kesejahteraan Di Kabupaten/Kota Provinsi Jawa Tengah Dalam Era Desentralisasi Fiskal. Jurnal Bisnis dan Ekonomi, 16(01), 24259.

Senik, C. (2005). Income Distribution and Well-Being: What Can We Learn From Subjective Data?. Journal of Economic Surveys, 19(1), 43-63.

Sidiq, R. S. S., \& Achmad, R. W. W. (2020). Gender aspects in remote indigenous community empowerment program in Indonesia. Journal of Advanced Research in Dynamical and Control Systems, 12(6), 2104-2109. https://doi.org/10.5373/JARDCS/V12I6/S20201172

Sidiq, R. S. S., \& Jalil, A. (2021). Virtual World Solidarity: How Social Solidarity is Built on the Crowdfunding Platform Kitabisa. com. Webology, 18(1).

Soleh, A. (2014). Pertumbuhan Ekonomi Dan Kemiskinan Di Indonesia. EKOMBIS REVIEW: Jurnal Ilmiah Ekonomi Dan Bisnis, 2(2).

Sudarlan. (2015). Pertumbuhan Ekonomi, Ketimpangan dan Kemiskinan di Indonesia. Jurnal EKSIS, 11 (1).

Sugiyono. (2013). Statistik Untuk Penelitian. Bandung: Alfabeta.

Sulistiawati, R. (2012). Pengaruh Investasi Terhadap Pertumbuhan Ekonomi dan Penyerapan Tenaga Kerja serta Kesejahteraan Masyarakat di Provinsi di Indonesia. Jurnal Ekonomi Bisnis dan Kewirausahaan, 3(1), 29-50.

Suliswanto, M. S. W. (2010). Pengaruh produk domestik bruto (PDB) dan indeks pembangunan manusia (IPM) terhadap angka kemiskinan di Indonesia. Jurnal Ekonomi Pembangunan, 8(2), 357-366.

Suryawati, C. (2005). Memahami Kemiskinan Secara Multidimensional. Jurnal Manajemen Pelayanan Kesehatan, 8(03). 
Todaro, M. P. (1977). Economic Development In The Third World: An Introduction To Problems And Policies In A Global Perspective. Pearson Education.

Todaro, M. P., \& Smith, S. C. (2020). Economic Development. Pearson UK.

Wijayanto, R. D., \& Arianti, F. (2010). Analisis Pengaruh PDRB, Pendidikan dan Pengangguran Terhadap Kemiskinan Di Kabupaten/Kota Jawa Tengah Tahun 20052008 (Doctoral Dissertation, Universitas Diponegoro).

Yuliani, T. (2015). Pertumbuhan Ekonomi dan Ketimpangan Pendapatan Antar Kabupaten di Kalimantan Timur. JEJAK: Jurnal Ekonomi dan Kebijakan, 8(1).

Zuhdiyaty, N., \& Kaluge, D. (2017). Analisis Faktor-Faktor Yang Mempengaruhi Kemiskinan Di Indonesia Selama Lima Tahun Terakhir. Jurnal Ilmiah Bisnis dan Ekonomi Asia, 11(2), 27-31. 